\title{
RETHINKING READINESS
}





\title{
RETHINKING READINESS
}

\author{
A Brief Guide to Twenty-First-Century \\ Megadisasters
}

\section{JEFF SCHLEGELMILCH}

Foreword by Irwin Redlener

Columbia University Press

New York 


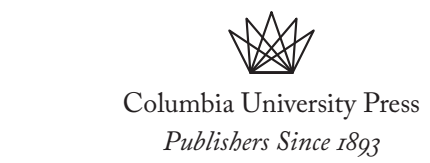

New York Chichester, West Sussex

cup.columbia.edu

Copyright (C) 2020 Columbia University Press

All rights reserved

\section{Library of Congress Cataloging-in-Publication Data}

Names: Schlegelmilch, Jeffrey, author.

Title: Rethinking readiness : a brief guide to twenty-first-century megadisasters / Jeff Schlegelmilch ; foreword by Irwin Redlener.

Description: New York : Columbia University Press, [2020] |

Includes bibliographical references and index.

Identifiers: LCCN 2020002493 | ISBN 978023 II90404 (cloth) | ISBN 978023II904II (paperback) | ISBN 9780231548878 (ebook) Subjects: LCSH: Emergency management. | Natural disasters. |

Risk management. | Natural disaster warning systems.

Classification: LCC HV 55 I.2 . $\mathrm{S}_{37} 2 \mathrm{O} 2 \mathrm{O} \mid \mathrm{DDC}_{363.34 / 7}$-dc23

$\mathrm{LC}$ record available at https://lccn.loc.gov/2020002493

Columbia University Press books are printed on permanent and durable acid-free paper.

Printed in the United States of America

Cover design: Milenda Nan Ok Lee

Cover art: (C) Shutterstock 
For Melinda, for showing that our actions are what make the world a fairer and more compassionate place.

And for Adelae, for showing that the future is bright and worth working toward with everything we have.

$$
\text { מ }
$$


